\title{
Helping Teens Answer the Question "Who Am I?": Social Development in Adolescents ${ }^{1}$
}

\author{
Rosemary V. Barnett ${ }^{2}$ \\ This is the third of a four-part series that will \\ explore adolescence in terms of physical, cognitive, \\ social, and moral development. This publication will \\ focus on the social development that adolescents \\ experience.
}

The journey from childhood to adolescence is very challenging. Between the ages of 10 and 17 there are major changes in physical, cognitive, social, and moral development. The major task for adolescents is to establish their self-identity. By determining - as best they can - a sense of who they are, they attempt to find a group that reflects or reinforces this self-identity. The group allows them to feel that they stand out from the crowd. This phase of development allows the adolescent to search for their sense of self. This is in order to answer the increasingly important question that they could not consider in earlier stages of development: "Who am I?"

\section{Social Development}

The next phase of adolescent development that is occurring at this same time is that of the teens social development. With the help of cognitive development, they begin to form an organized system of personality traits. These traits allow them to form a self-concept. Self-concept is a set of attributes, abilities, attitudes, and values that an adolescent believes defines who he or she is. The ability to think in new ways allows them to add new aspects of self-esteem (how they feel about their "self"). This can occur through life experiences such as learning to do a job, romantic appeal, and close friendships.

Self-esteem continues to rise during adolescence. As they gain confidence and self-awareness, they begin forming a self-identity. This sense of self makes them more comfortable with others. How they develop as a person is based on their perceptions of organized character sketches. These sketches come together through new perspective taking. This happens largely as the result of their social interactions. They become more able to develop friendships that are based on loyalty and intimacy. These are different than their younger friendships,

1. This document is FCS2242, one of a series of the Family, Youth and Community Sciences Department, Florida Cooperative Extension Service, Institute of Food and Agricultural Sciences, University of Florida. Original publication date December 6, 2005. Visit the EDIS Web Site at http://edis.ifas.ufl.edu.

2. Rosemary V. Barnett, assistant professor, Department of Family, Youth and Community Sciences, Cooperative Extension, Institute of Food and Agricultural Sciences, University of Florida, Gainesville, FL 32611.

The Institute of Food and Agricultural Sciences (IFAS) is an Equal Opportunity Institution authorized to provide research, educational information and other services only to individuals and institutions that function with non-discrimination with respect to race, creed, color, religion, age, disability, sex, sexual orientation, marital status, national origin, political opinions or affiliations. U.S. Department of Agriculture, Cooperative Extension Service, University of Florida, IFAS, Florida A. \& M. University Cooperative Extension Program, and Boards of County Commissioners Cooperating. Larry Arrington, Dean 
which are based more on mutual trust and assistance. These social milestones occur slowly over time. Social experiences allow them to take on new adult-like behaviors. Remember, they are trying to learn how to function in a more grown-up world.

\section{Peers and Friends; Friends and Family}

Peers are people who have certain aspects of their status in common, such as being the same age. For adolescents, peers can be a term used for other adolescents that make up a large network of their classmates, community members, or coworkers who are about the same age. Friends tend to be an adolescents peers, people who are about the same age, but all peers may not be friends. Friends are those peers that an adolescent has developed a valued, mutual relationship with (Arnett, 2001).

An interesting fact relating to adolescence is that as time spent with family decreases, the amount of conflict with parents increases (Larson \& Richards, 1994). The level of warmth and closeness between parents and their children also typically declines during adolescence. All this usually results in adolescents moving away from spending time with their families and spending more time with their friends. This time is spent not only during the school day, but after school, in the evenings, on weekends, and even during summer breaks.

In fact, time spent with family decreases by about half from $5^{\text {th }}$ to $9^{\text {th }}$ grade, then drops even more from $9^{\text {th }}$ to $12^{\text {th }}$ grade. Time spent with friends increases. Time spent alone also increases, especially for boys. One study found that the average time adolescents ages 13-16 years old spend with their parents was only 28 minutes a day! Time spent with friends, however, was four times greater at 103 minutes per day (Buhrmester \& Carbery, 1992).

\section{Topics with Friends or Family}

Teenagers change in other means of social development. They lean on their parents as their main sources of support until around $7^{\text {th }}$ grade. Then they move into adolescence and lean on not just their parents, but their same-gender friends as equal means of support. By $10^{\text {th }}$ grade, adolescents lean more on their same-gender friends than their parents. By emerging adulthood (typically college students), they lean more on their romantic partners for their main sources of support (Furman \& Buhrmester, 1992).

When adolescents need to talk about their personal feelings, sorrows, or secrets, they tend to go to their best friend or their relationship partner. Parents are not in their inner circle as much when it comes to these topics anymore. They do like to talk to their parents about other things. Usually relating to how well they are doing in school, their career goals, and their hopes and plans for the future. They prefer to talk to their friends about their attitudes about marriage, their views on sex, problems with the opposite sex, and feelings about the opposite sex (Furman \& Buhrmester, 1992).

\section{Tips for Agents and Parents}

Now that we have a sense of some of the important social changes that occur during adolescence, we can use this information to help us understand teens. It will also help us recognize their sensitive thoughts and feelings. And we can use it to help us direct them toward positive behavior and outcomes.

Parents can help their adolescents by providing support when they need it. This may mean that parents will need some patience and understanding when they begin to see their teenager lean more on their friends and less on them. It is easy to feel a sense of loss over this shift in adolescence when they begin getting advice on social relationships from their friends.

Parents may feel better when they understand that this is a sign of maturity and a natural process. They can further accept this change by knowing that their teenager still needs them. They can guide them into good academic decisions, making realistic career goals, and plans for the future. All very important parts of an adolescent's daily thoughts and all critical to their success. If parents focus on providing the support that they need during this time, it will help their adolescent transition through social development changes with less stress and with more positive outcomes. 


\section{References}

Arnett, Jeffrey J. (2001). Adolescence and Emerging Adulthood. Upper Saddle River, NJ: Prentice-Hall, Inc.

Berk, Laura E. (2000) Child Development, $5^{\text {th }}$ Edition. Needham Heights, MA: Allyn and Bacon.

Buhrmester, D. \& Carbery, J. (1992, March). Daily patterns of self-disclosure and adolescent adjustment. Paper presented at the biennial meeting of the Society for Research on Adolescence, Washington, D.C.

Furman, W. \& Buhrmester, D. (1992). Age and sex differences in perceptions of networks of personal relationships. Child Development, 63, 103-115.

Wheeler, M.D. (1991). Physical changes of puberty. Endocrinology and Metabolism Clinics of North America, 20, 1-14. 